\title{
Antitrust and Core Theory*
}

\author{
John Shepard Wiley Jr. $\dagger$
}

Economists have kicked antitrust law around a lot in the last couple of decades but one thing has seemed clear: at least they have agreed that antitrust should outlaw per se horizontal agreements that explicitly and exclusively fix prices or restrain output. Recently, however, some economists have challenged even this remnant of doctrinal tradition. Using a part of game theory known as core theory, these economists suggest that horizontal agreements among competitors to restrain output sometimes can be essential for productive efficiency. ${ }^{1}$ One commentator rightly remarks that this work "strike[s] at the root of orthodox antitrust doctrine, even of the economic kind."2 Professor Lester Telser of the University of Chicago Department of Economics is the most prominent advocate of core theory. ${ }^{3}$

Virtually all courts and commentators accept economic effi-

* $\odot 1987$ by John Shepard Wiley Jr.

$\dagger$ Professor of Law, UCLA School of Law. I thank but disassociate from my conclusions William Alford, Robert Boyd, Frank Easterbrook, Richard Epstein, Victor Goldberg, Dan Lowenstein, Roger Noll, Eric Rasmusen, Lester Telser, Stephen Yeazell, and a number of anonymous reviewers. The John M. Olin Foundation supported part of this work.

1 See Lester G. Telser, Cooperation, Competition, and Efficiency, 28 J. L. \& Econ. 271 (1985); George Bittlingmayer, Decreasing Average Cost and Competition: A New Look at the Addyston Pipe Case, 25 J. L. \& Econ. 201 (1982); George Bittlingmayer, Price-Fixing and the Addyston Pipe Case, 5 Res. L. \& Econ. 57 (1983); George Bittlingmayer, Did Antitrust Policy Cause the Great Merger Wave?, 28 J. L. \& Econ. 77 (1985).

2 Wesley J. Liebeler, Comments, 28 J. L. \& Econ. 335, 338 (1985).

3 That Professor Telser is disputing conventional antitrust wisdom is not surprising. Telser also reached unconventional conclusions the first time he published an article in the Journal of Law and Economics, more than a quarter century ago, and the shock waves are still rolling. See Lester G. Telser, Why Should Manufacturers Want Fair Trade?, 3 J. L. \& Econ. 86 (1960), which is now a classic explanation of how a producer might serve the public interest by using vertical restraints to promote economic efficiency. Although not stating as much, Telser's 1960 article implied that current law was misguided, by offering an efficiency justification for then-illegal practices. Decades later the Supreme Court cited legal commentators who had popularized Telser's work when the Court agreed that it was misguided to treat vertical arrangements with unmitigated hostility. See Continental T.V., Inc. v. GTE Sylvania Inc., 433 U.S. 36, 55-56 (1977) (citing Judges Bork and Posner, who refer to Telser's work). Comanor reviews the importance of Telser's article to the Sylvania decision. William S. Comanor, Vertical Price-Fixing, Vertical Market Restrictions, and the New Antitrust Policy, 98 Harv. L. Rev. 983, 986-90 (1985). One might conclude that when Telser speaks, antitrust should listen. 
ciency as at least one relevant antitrust consideration. ${ }^{4}$ Accordingly, lawyers and judges in this supposedly statutory field are condemned to struggle perpetually with the latest news from the theory front. Federal judges are the primary architects of American competition policy, a role forced upon them by Congress's traditional reluctance to elaborate on the broad sweep of the antitrust laws. The common law nature of antitrust thus poses the question of how judges should respond to Telser's work on core theory. I contend that they should wholly ignore core theory's implications for antitrust. My presentation has two parts. Part I offers a lay explanation of core theory and the relevant literature. ${ }^{s}$ Part II presents my contention that judges should refuse to dilute antitrust's per se rules on the basis of what is currently known of core theory.

\section{Core Theory: Where It Came From and What It Is}

Game theory uses formal mathematical models to represent situations of conflict. It has been around for some forty years ${ }^{6}$ and has developed two styles or directions: noncooperative and cooperative games. Noncooperative game theorizing, typified by the famous prisoners' dilemma, assumes that players cannot converse and make mutually binding commitments. ${ }^{7}$ On the other hand, cooperative game theory assumes players have perfect ability to communicate and contract. ${ }^{8}$ Accordingly, players can form coalitions: agreements with other players. In fact, a player's only decision in a cooperative game concerns which coalition to enter in order to maximize that player's personal benefit." The "core" is a key notion in cooperative game theory. ${ }^{10}$ The core of a game has a precise

4 For a survey of the literature and relevant cases, see John Shepard Wiley Jr., A Capture Theory of Antitrust Federalism, 99 Harv. L. Rev. 713, 748-51 \& n.166 (1986). Even commentators using Foucault and Derrida to analyze antitrust seem to count economic efficiency among the legitimate "traditional sociopolitical voices" in the debate. See Rudolph J. Peritz, The Predicament of Antitrust Jurisprudence, 1984 Duke L. J. 1205, 1207 n.2, 1295.

- This section proceeds at a level and length that will bore the mathematically literate, who should skip it entirely. The common law nature of antitrust, however, increasingly has raised an issue of competence: can the lawyers who present antitrust cases and the judges who make the law grasp what mathematical theorists like Telser are talking about? It is this legal audience that $I$, as a lawyer, primarily wish to address-well understanding that my low-brow decoding risks contempt.

- See John von Neumann and Oskar Morgenstern, Theory of Games and Economic Behavior (1944).

7 See, e.g., Robert Axelrod, The Evolution of Cooperation 7-10 (1984).

- See John Nash, Two-Person Cooperative Games, 21 Econometrica 128, 128-29 (1953).

- See William W. Sharkey, The Theory of Natural Monopoly 113 \& n.I (1982).

10 The core has precursors in the last century, but it was introduced as such in 1953 by 
mathematical definition, ${ }^{11}$ but an intuitive appreciation of the idea is all that is needed to understand the problems with applying its policy prescriptions to antitrust law. To this end, I first offer a general verbal definition of the core and then turn to particular illustrations of what it means in practice.

\section{A. The Core in Cooperative Game Theory}

Cooperative game theory assumes a game that has some payoff to individual players. It also assumes individual, self-interested rationality: players of a game will bargain with each other and form coalitions to do as well as possible for themselves. The core of a game is the set of solutions that leaves no coalition in a position to improve the payoffs to all of that coalition's members. A solution (or imputation) in the core thus offers no possible subset of players an option to defect to a different coalition and do better on their own. If some group can improve its collective lot by playing a different way, then that subset will reconstitute itself as a new coalition that will play the game in a different way and, hence, distribute the game's proceeds differently. Because the new coalition will block the first round's result from emerging as the stable or permanent resolution of the game, the first round solution is said to be outside the core. If some new coalition of players can block all possible solutions of a game, no solution is within the core. Synonymously, any such game has an empty core. ${ }^{12}$

Examples can clarify these general ideas. The game of "split

Gillies and by Shapely in unpublished works. The idea surfaced in specialized publications later in the 1950s. See R. Duncan Luce and Howard Raiffa, Games and Decisions 192-98 (1957); Donald B. Gillies, Solutions to the General Non-Zero-Sum Games, 40 Annals of Math. Studies 47 (1959); Martin Shubik, Edgeworth Market Games, 4 Contributions to the Theory of Games 47, 267 (1959). Nonetheless, core theory did not appear in mainstream economic journals until the mid-1960s. See Robert J. Aumann, Existence of Competitive Equilibria in Markets with a Continuum of Traders, 34 Econometrica 1, 16-17 (1966); Lloyd S. Shapley and Martin Shubik, Quasi-Cores in a Monetary Economy with Nonconvex Preferences, 34 Econometrica 805 (1966); Lloyd S. Shapley and Martin Shubik, On the Core of an Economic System with Externalities, 59 Amer. Econ. Rev. 678 (1969). The American Economic Review did not presume familiarity with the core even in the mid-1970s. See Gerald R. Faulhaber, Cross-Subsidization: Pricing in Public Enterprises, 65 Amer. Econ. Rev. 966, 968-69 (1975).

1 For concise presentations, see, for example, Martin Shubik, Game Theory in the Social Sciences 145-50 (1982); Sharkey, Natural Monopoly at 114-23 (cited in note 9); Lester G. Telser, Economic Theory and the Core 3-4 (1978); Bittlingmayer, 5 Res. L. \& Econ. at 114-21 (cited in note 1).

12 See, e.g., Aumann, 34 Econometrica at 16 (cited in note 10); Shapley and Shubik, 59 Amer. Econ. Rev. at 679 (cited in note 10). 
the gift" has a core under certain conditions. ${ }^{13}$ Suppose Peggy, hoping to promote communication and accord, promises to give $\$ 3$ million to three artists $(A, B$, and $C)$ on the condition that they formulate and unanimously agree on some way to split the sum among themselves. If they fail to reach unanimous agreement on a division, Peggy will give a total of $\$ 1.5$ million to any two who can agree on how to divide that award; the third artist gets nothing. She will give nothing if none of the artists can agree.

This game has a core. The reason is that the artists can divide $\$ 3$ million into three shares so that any two shares add up to at least $\$ 1.5$ million. This is true, for instance, for an even three-way split. To see why this is crucial, assume that the three artists tentatively arrange for an equal division of the cash and then ask yourself whether any two of them-say, artists $A$ and $B$-could do better on their own. Here, they cannot. Two artists who agree get only $\$ 1.5$ million while they would get a total of $\$ 2$ million under the three-way equal division. Therefore, no two artists will "block" this agreement among all three.

Another imputation in the core of Peggy's game is $\$ 1,1.4$, and 0.6 million. If artists $A$ and $B$ agree that the first takes $\$ 1$ million and the second takes $\$ 1.4$ million, artist $C$ can arrange no better deal. To block the three-way agreement, artist $C$ would have to offer artist $A$ more than $\$ 1$ million to induce her cooperation. Likewise, artist $C$ would have to offer artist $B$ more than $\$ 1.4$ million to induce her cooperation. But a two-artist coalition can get only $\$ 1.5$ million; whichever other artist she approaches, artist $C$ will be left with less than $\$ 0.5$ million-which is less than she gets under the original $(1,1.4,0.6)$ three-way split.

Vary the rules of this game some and the core can disappear. This will happen if Peggy raises the award she will give to any twoartist coalition from $\$ 1.5$ to $\$ 2.5$ million. It is impossible to divide $\$ 3$ million into three sums so that any two shares add up to at least $\$ 2.5$ million. Thus the core is empty. Consider intuitively how any tentative three-way equal split now becomes unstable: any pair, say artists $A$ and $B$, can both improve their situation by agreeing to cut artist $C$ out of the deal and to divide the $\$ 2.5$ million between themselves. Artists $A$ and $B$ both would prefer, for instance, the even split of $(1.25,1.25)$ to $(1,1,1)$. But if artists $A$ and $B$ reach this agreement, artist $C$ can disrupt it by offering one of them a bigger share of the $\$ 2.5$ million-for instance, $(1.5,1)$-if

13 Adapted from Shapley and Shubik, 59 Amer. Econ. Rev. at 679 (cited in note 10). 
that artist will join with artist $C$ in a new coalition. But say artist $A$ makes this deal with artist $C$; artist $B$ then can disrupt it by offering either one a larger piece of the $\$ 2.5$ million. And so on. There is no stable coalition of either two or three artists; this game has an empty core.

Games without cores can exist in an infinite array of settings. "Waste disposal" and "taxi trip" are two further illustrations. In the first game, the Environmental Protection Agency asks three similar towns $(A, B$, and $C$ ) to decide how many waste disposal permits they require. ${ }^{14}$ This game has no core, for example, if the costs of waste disposal plants are $\$ 3$ million for a one-town system, $\$ 4$ million for a two-town system, and $\$ 6.6$ million for a three-town system. It is socially optimal to install a three-town system for the three towns. Yet no stable coalition can convince each town that the three-town system is in its individual best interest. If the towns decide to split the three-town cost equally at $\$ 2.2$ million each, any two towns will prefer to opt for a two-town system at $\$ 2$ million each. If towns $A$ and $B$ tentatively reach this agreement, however, town $C$ (facing a $\$ 3$ million bill for a one-town system) should be willing to offer one of the others the two-town deal at a cheaper price (say, $\$ 1.5$ million for town $A$ and $\$ 2.5$ million for town $C$ ). This coalition in turn is vulnerable to further raiding by the excluded town $B$. And so on. This game has an empty core.

The core is also empty for certain versions of the game of "taxi trip."1s For example, say that three strangers are willing to pay up to $\$ 7$ each for a cab to the airport. Two cabs stop nearby. Each cab can carry one or two passengers, and each driver is willing to make the trip (with either one or two passengers) for a minimum of $\$ 6$. Given these demands and costs, the worst-off or excluded player can block any arrangement by tempting some players to abandon others for a more attractive arrangement. Suppose, for instance, passengers $A$ and $B$ force driver $X$ down to her minimum $\$ 6$ total fare, thus yielding for $A$ and $B$ a fare of $\$ 3$ each. As a result, passenger $C$ is stuck paying at least $\$ 6$ to travel alone with driver $Y$. But driver $X$ could gain an added $\$ 2$ by dumping $B$ and offering $C$ a ride for $\$ 5$-which $C$ should accept because a $\$ 5$ fare is cheaper than a $\$ 6$ fare. This new coalition between $X, A$, and $C$, however, is vulnerable in turn to raiding by the excluded players, $Y$ and $B$. Now passenger $B$ faces a trip alone with driver $Y$ at a fare of at least $\$ 6$, and both will improve their lots if they attract passenger

14 Adapted from Faulhaber, 65 Amer. Econ. Rev. at 974 (cited in note 10).

${ }^{16}$ Taken from Bittlingmayer, 28 J. L. \& Econ. at 81-82 (cited in note 1). 
$C$ with a $\$ 4$ fare offer, which $Y$ and $B$ split between themselves and which $C$ will prefer to the $\$ 5$ that $C$ pays as a member of the existing $X-A-C$ coalition. This coalitional instability occurs for every possible combination of players.

These three examples illustrate two key properties of the core. First, core theory predicts whether a game will enjoy a particular type of equilibrium. Games with cores have the potential for achieving stability-dissatisfied players are unable to achieve successful renegotiation. Conversely, games without a core lack the possibility for any such stable resolution. Second, the core of a game depends crucially on the rules of the game and the number of players. Vary the regime or the number of players and imputations in the core will change: the core may vanish entirely or games with empty cores may develop stable imputations.

Significantly, however, core theory cannot predict which of several stable solutions will result when the core contains more than than one imputation, nor can it predict what will happen when the core is empty. When the core contains many solutions, the players' choice among them depends on other considerations. ${ }^{18}$ When the core is empty, players might continue to bargain at great length, ${ }^{17}$ might achieve a resolution that is "a transient event in some dynamic process,"18 or might respond to "social, cultural, or institutional restraints" that stifle continued bargaining but are not captured by the model of the game. ${ }^{19}$

\section{B. The Core Comes to Antitrust}

Core theory made several notable advances in economic theory, ${ }^{20}$ but it remained well outside the ken of lawyers and legal analysts until the 1980s. Telser published two books on the subject in the $1970 \mathrm{~s},{ }^{21}$ but the antitrust literature of the time took no note of them. This neglect was no doubt partly due to the books' forbiddingly mathematical character, ${ }^{22}$ as well as to their air of high the-

16 See Shubik, 4 Contributions to the Theory of Games at 277 (cited in note 10).

17 Shubik, Game Theory in the Social Sciences at 150 (cited in note 11).

1* Martin Shubik, A Game-Theoretic Approach to Political Economy 360 (1984) (emphasis removed).

19 Shapley and Shubik, 34 Econometrica at 823 (cited in note 10). See also Shubik, Game Theory in the Social Sciences at 150, 176 n.25 (cited in note 11).

${ }^{20}$ See, e.g., Gerard Debreu and Herbert Scarf, A Limit Theorem on the Core of an Economy, 4 Int'l Econ. Rev. 235 (1963).

${ }^{21}$ Lester G. Telser, Competition, Collusion, and Game Theory (1972); Telser, Economic Theory and the Core (cited in note 11).

${ }^{22}$ See Varouj A. Aivazian and Jeffrey L. Callen, The Coase Theorem and the Empty 
ory to the exclusion of specific policy applications. It was not until 1981 that Aivazian and Callen introduced Journal of Law and Economics readers to core theory and noted its implications for the Coase theorem. ${ }^{23}$ Their point was that an assumption of zero transaction costs need not imply Coase's famous conclusion that firms will produce efficiently. Rather, they argued that empty cores block proof that bargaining leads to efficiency, because firms might recontract endlessly when the core is empty. Aivazian and Callen were careful to disavow the stronger claim that inefficiency necessarily follows from an empty core. Rather, they stressed that "[i]t is an empirical question as to what happens when the core is empty. We do not know."24

1. Bittlingmayer's 1982 Addyston article. Core theory first greeted the lay antitrust world one year later. In 1982 George Bittlingmayer, who wrote his dissertation at Chicago under Telser's supervision, applied core theory to the landmark antitrust case of Addyston Pipe. ${ }^{25}$ This decision condemned a cartel of cast-iron pipe manufacturers in the late nineteenth century. By focusing on an antitrust classic, Bittlingmayer set his sights on big game.

Bittlingmayer's examination of Addyston begins by noting that, in theory, competitive equilibrium cannot exist when (1) industries are composed of plants with identical U-shaped cost curves (which Telser termed "Viner industries" after a famous article by Jacob Viner) and (2) industries face either uncertain demand, avoidable operating costs, or the costs associated with idle plants. To explain the second situation, Bittlingmayer offers the standard natural monopoly story that short-run marginal cost pricing will not permit an optimally sized firm or industry to recover its costs if long-run average costs are falling. In a summary that bespeaks the world view of core theory, Bittlingmayer recounts that "restrictions on recontracting" can mitigate this disequilibrium if the restrictions prevent subsets of players "from undermining arrangements that cover cost." The one specific recontracting restriction that Bittlingmayer mentions would place "all

Core, 24 J. L. \& Econ. 175, 175 (1981) (economists citing Telser's 1972 book and commenting on "the slow diffusion of mathematical economics to the remainder of the profession").

${ }^{23}$ Id. The authors refer readers to Telser's 1972 book for fuller treatment of the theory of the core. Id. at 175 n.4.

24 Id. at $180-81,180$.

${ }^{25}$ United States v. Addyston Pipe \& Steel Co., 85 F. 271 (6th Cir. 1898), affirmed, 175 U.S. 211 (1899). Judge Bork heralded the decision as "one of the greatest, if not the greatest, antitrust opinions in the history of the law." Robert H. Bork, The Antitrust Paradox 26 (1978). 
supply or all demand . . . under the control of one agent"-a situation others typically describe as monopoly or monopsony. Bittlingmayer states that, absent the possibility of competitive equilibrium, "some noncompetitive, cooperative solution to market allocation is necessary." It therefore "becomes unrealistic to expect competitive behavior in certain markets because firms could not behave competitively even if they wanted to."26

After this explanation, Bittlingmayer tries to document that the Addyston defendants faced cost conditions that fit this theory: positive avoidable costs, as well as declining long-run average costs and declining short-run marginal costs. He concludes that the pipe industry could not have achieved competitive equilibrium. ${ }^{27}$ Therefore the cartel was at least an inevitable ${ }^{28}$ and perhaps even a desirable $^{29}$ development, one perhaps better explained by the cartel's desire to establish industry equilibrium than by the price-gouging collusion that conventional cartel theory posits. ${ }^{30}$

This conclusion seems sensational. Bittlingmayer has unmasked a supposed triumph of antitrust as a hopeless attempt to enforce competition where cooperation was inevitable because competition could not succeed. Commentators agreed that the result was startling: "It is more than a bit disturbing to be told that the case that laid the basic groundwork for the economic approach to antitrust involved conditions such that competition could not have existed."31 In his article, however, Bittlingmayer introduces doubt about the implications of his work for antitrust policy by suggesting that government regulation or ownership sometimes may be preferable to industry self-regulation..$^{32}$ Bittlingmayer summarizes this ultimately diffident attitude by stating that the article

${ }^{26}$ Bittlingmayer, 25 J. L. \& Econ. at 204-10, 208, 208, 202, 202 (cited in note 1).

27 Id. at 211.

28 Id. at $202,203$.

29 Id. at 210 ("the significance of the agreement and merger among the Addyston defendants may be that they provide an instance in which a competitive outcome could not be sustained and in which cartel restrictions promoted the production of a good by allowing firms to cover their costs").

so Id. at 202 ("The aim of this study is . . . to propose what may appear to be a novel explanation of the [Addyston] cartelization and merger."); id. at 208 ("Theoretical results of this sort suggest that a variety of business practices that appear anticompetitive can be interpreted as attempts to achieve stabilization in a market.").

${ }^{31}$ Liebeler, 28 J. L. \& Econ. at 338 (cited in note 2).

3225 J. L. \& Econ. at 203-04 (cited in note 1). In addition to cartelization, the impossibility of an equilibrium "can lead to state control of the enterprises or to state-sanctioned collusion" in the form of price fixing or geographic restrictions on dealings. Id. at 208. Bittlingmayer leaves "[a]n adequate discussion of this issue" to "a separate treatment." Id. at 204. 
has investigated a syllogism, the major premise of which is that increasing returns are incompatible with competition and the minor premise of which is that Addyston involved such an industry. ${ }^{33}$ But Bittlingmayer never identifies the syllogism's conclusion.

2. Bittlingmayer's 1983 Addyston article. The following year, Bittlingmayer published a second analysis of Addyston that contains more descriptive historical detail. It recounts the pipe industry's repeated cartelization efforts from 1879 to 1895; the discovery and prosecution of the Addyston pipe cartel in 1896; the formation of United States Cast Iron Pipe and Foundry through the merger of the cartel members in 1898; and cartels and mergers in industries closely related to cast-iron pipe manufacturing. Bittlingmayer elaborates on his earlier explanation that the industry's cost conditions made a competitive equilibrium impossible by arguing that the pipe industry in the late 1890 s was characterized by "cutthroat competition"-which is to say "pricing at marginal cost in an industry where marginal-cost pricing will not sustain its operation." He concludes that Addyston illustrates that one should not expect vigorous competition in the "typical industrial setting" because marginal-cost pricing will not cover the costs of production; instead, "one should expect the emergence of various arrangements that appear anticompetitive, because they allow production to take place."34 Moreover, the pipe buyers' lack of interest in breaking up the Addyston cartel suggests that they perceived this analysis and believed the cartel operated to their own long-run benefit. ${ }^{35}$

But once again Bittlingmayer forges revolutionary theory into confusing conclusions. In suggesting that the Addyston cartel was the inevitable, the "best of all possible worlds," Bittlingmayer is critical of the antitrust doctrine that outlaws such arrangements per se. Yet his final paragraph tosses off a tentative view wholly unanticipated by the rest of this article: the per se rule against horizontal agreements "may be best from a global point of view" because courts with "imperfect knowledge" will have difficulty "determining what sort of agreement should be allowed."36

ss Id. at 228.

s4 Bittlingmayer, 5 Res. L. \& Econ. at 90, 114 (cited in note 1).

so Id. at 113 ("IIf we] question the presumption that noncompetitive arrangements, including cartelization, have monopoly gain as their sole purpose[, we are forced] to recognize the possibility that buyers are not necessarily interested in breaking up price-fixing arrangements, which certainly appears to have been true in the case of Addyston."); id. at 107 ("If some buyers of cast-iron pipe paid more than marginal cost . . they may still have done so satisfied that this too was the best of all possible worlds").

se Id. at $107,114$. 
3. Bittlingmayer's 1985 merger wave article. Bittlingmayer's third core theory article repeats his theme that the theory exposes a competitive failure that coordination can solve. It notes that the coordination can take the form of either cartels or mergers and that antitrust creates efficiency losses if it forces firms to merge when they would prefer the looser structure of a cartel. However, the article does not directly defend this argument; it simply collects evidence that antitrust enforcement has influenced merger activity. This conventional showing has nothing to do with core theory. ${ }^{37}$ In terms of the core and the per se rule, the article's significance instead lies in its incidental policy equivocation that "while the [empty core] problem generated by fixed costs can be thought of as creating a 'natural monopoly,' in the sense that independent action and the price system do not lead to the optimal result, it is not clear that the ideal solution calls for either one firm or government regulation."38 Thus, the core remained a startling and confounding theoretical development.

4. Telser explains core theory for lawyers. In 1985, Telser himself first applied core theory to antitrust law, signaling a challenge to the per se rule by stating that "competition may require some cooperation in order to obtain efficiency." 39 The article's first main point is that "avoidable" supply costs can complicate the nature of competitive equilibrium. In Telser's usage, "avoidable costs" do not vary smoothly with output, are positive at positive rates of output, but are zero if output is zero..$^{40}$

Telser explains the problem in two steps. First, he establishes a mild paradox: society may want firms to stock more inventory than they expect to sell when supply costs are lumpy and must be incurred before demand is known with certainty-but ordinary arrangements make it unprofitable for firms to hold this excess in-

${ }^{37}$ Bittlingmayer allows as much. See 28 J. L. \& Econ. at 117 (cited in note 1).

38 Id. at 84.

30 Telser, 28 J. L. \& Econ. at 272 (cited in note 1). Telser moved from pure theory to applied policy by contributing to this symposium issue, which "was intended to explore the question how the antitrust laws should be changed to promote economic efficiency." Thomas Gale Moore, Introduction, 28 J. L. \& Econ. 245, 245 (1985).

40 Telser elsewhere uses an airplane to illustrate the concept. If we assume that a plane making a flight incurs a set but not a sunk cost (fuel, pilot, and cabin labor), this cost is independent of the number of passengers on the airplane and could be avoided if the plane did not make the flight. See Telser, Economic Theory and the Core at 43 (cited in note 11). The example of avoidable cost that Telser's 1985 article uses is a one-good store that each morning must decide how much perishable inventory (or "capacity") to buy. Telser, $28 \mathrm{~J}$. L. \& Econ. at 277-78 (cited in note 1). These intermediate costs fall between the conventional categories of fixed and variable, a fact that Bittlingmayer illustrates by describing them as "fixed avoidable" or "semivariable" costs. 5 Res. L. \& Econ. at 117 (cited in note 1). 
ventory. ${ }^{41}$ Telser concludes that long-term contracting can overcome this drawback, ${ }^{42}$ thus illustrating another way that long-term contracts can reduce uncertainty and thereby create gains. This analysis joins the ever-expanding list of justifications for such contracts $^{43}$ but poses no necessary challenge to antitrust's conventional hostility to cartels.

Telser's second step involves the far more unconventional claim that in common circumstances firms will have to cooperate to establish industry-wide production quotas if efficient production levels are to be possible. ${ }^{44}$ Telser's general claim is that firms in certain kinds of markets often will be unable to respond stably to demand. The six special characteristics defining markets to which Telser's analysis applies are (1) uncertain demand, (2) scale economies in production, (3) avoidable supply costs, (4) products that cannot be stored cheaply, (5) fixed firm capacities, and (6) firm capacities that are large relative to demand. ${ }^{45}$

These assumptions presume an industry in which optimality requires that changing demand be met by selectively choosing the right combination from a menu of available plants, each of a fixed capacity and a different size. By definition, it is impossible in this world to meet aggregate demand by discretely adjusting the output of any individual plant. It is as if plants are piano keys and various levels of demand are chords: optimal supply and sweet music both require the Invisible Hand to hit the correct-but only the correct-combinations. By assuming a world in which unique coali-

41 Telser's article assumes that goods cannot be stored for sale in later periods. To do so could collapse the category of avoidable cost into the more traditional category of variable cost and thus moot this particular analysis. See Telser, 28 J. L. \& Econ. at 278 (cited in note 1). In his 1978 book, Telser devotes substantial theoretical and empirical attention to the economics of storage. See Telser, Economic Theory and the Core at 175-256 (cited in note 11). See also Bittlingmayer, 25 J. L. \& Econ. at 209 (cited in note 1).

42 Telser, 28 J. L. \& Econ. at 274-76, 277-78, 284-85 (cited in note 1).

43 See Oliver E. Williamson, Markets and Hierarchies: Analysis and Antitrust Implications (1975); Benjamin Klein, Robert G. Crawford, and Armen A. Alchian, Vertical Integration, Appropriable Rents, and the Competitive Contracting Process, 21 J. L. \& Econ. 297 (1978); Victor P. Goldberg, The Free Rider Problem, Imperfect Pricing, and the Economics of Retailing Services, 79 Nw. U. L. Rev. 736 (1984).

4 Telser, 28 J. L. \& Econ. at 290 (cited in note 1) ("If there is to be an efficient supply response for arbitrary rates of demand, then some cooperation among the participants is necessary"); id. at 293 ("Cooperation among the firms with respect to these reductions [resulting from output quotas] is necessary to attain the efficient result").

45 Telser's results do not depend on scale economies if one assumes demand is certain and plants are available only in fixed, identical sizes. See Telser, Economic Theory and the Core at 106-17 (cited in note 11). As Bittlingmayer notes, the latter assumption is unrealistic because generally plants exist in a range of sizes. Bittlingmayer, 5 Res. L. \& Econ. at 6162 (cited in note 1 ). 
tions of active producers and customers create optimality, Telser's article envisions a market that core theory can analyze.

Telser illustrates his analysis with a numerical example. He assumes that each of an uncertain number of consumers (ranging from eight to fifteen) is willing to pay $\$ 5$ for no more than one unit of a product. He further assumes that four firms make the relevant product and that the firms have the following capacities (or "inventory" sizes) and avoidable costs:48

$\begin{array}{lll}\text { Firm 1 } & \text { Inventory }=1 & \text { Avoidable Cost }=\$ 5 \\ \text { Firm 2 } & \text { Inventory }=2 & \text { Avoidable Cost }=\$ 8 \\ \text { Firm 3 } & \text { Inventory }=4 & \text { Avoidable Cost }=\$ 12 \\ \text { Firm 4 } & \text { Inventory }=8 & \text { Avoidable Cost }=\$ 16\end{array}$

Optimal supply requires unique combinations of plants at different random levels of demand. For example, suppose demand is for 8 units. The cheapest way to produce 8 units is to operate Firm 4 (at an avoidable cost of \$16) and to idle the other three plants. All other supply combinations are more costly. Similarly, at a demand of 10 the uniquely efficient supply response is to run Firms 2 and 4 and to idle Firms 1 and 3.

Telser uses core theory to analyze, as a game, the process of finding optimal supply combinations for different demand levels for this example. This game assumes that, in any given time period, customers "arrive" in the market and thus determine with certainty the level of demand. These customers and the firms then bargain with each other to form the most advantageous coalitions. Telser makes two key points: first, this game does not have a core at every level of demand, but second, imposing output quotas on the firms can assure that the core always exists. ${ }^{47}$

In detail, Telser's first point is that the core of this game is empty half of the time; at demand levels of $9,10,11$, and 13 there is no assurance that the socially efficient supply coalition will reach a stable equilibrium. To grasp Telser's point, consider at length what happens when demand is 8 and 10.

When total demand (randomly) equals 8 , a social planner concerned with global efficiency would maximize social gain or surplus by ordering only Firm 4 to operate. This arrangement would yield a net coalition surplus of $\$ 24$ (eight consumers value output at $\$ 5$

16 Telser, 28 J. L. \& Econ. at 286 (cited in note 1).

17 Id. at $290,293$. 
per unit for a total benefit of $\$ 40$, minus Firm 4's avoidable production cost of \$16). This social optimum is in the core, which is to say the arrangement is stable from the standpoint of individual producers and customers.

For an intuitive explanation, examine the incentives that tempt coalition members to defect. How the producers and customers divide the $\$ 24$ surplus among themselves depends on the credible defection options or potential blocking threats they each possess. For the coalition of eight customers and Firm 4 (which Telser denotes as " $\left(8 \mathrm{~B}, \mathrm{~A}_{4}\right)$ "), any four customers can threaten to defect to Firm 3 in a coalition ( $4 \mathrm{~B}, \mathrm{~A}_{3}$ ), where the customers stand to reap a maximum of $\$ 2$ each. This maximum share is $\$ 2$ because coalition ( $4 \mathrm{~B}, \mathrm{~A}_{3}$ ) has a total surplus of $\$ 8$ (four customers at $\$ 5$ demand each, minus $\$ 12$ avoidable cost). The four customers in $\left(4 \mathrm{~B}, \mathrm{~A}_{3}\right)$ thus can receive a maximum share of $\$ 2$ each if the coalition allocates all gain to customers. Accordingly, the coalition (8B, $A_{4}$ ) will have to offer customers a share of at least $\$ 2$ each to prevent their defections to the next-best coalition ( $\left.4 \mathrm{~B}, \mathrm{~A}_{3}\right)$.

This same threat also establishes the minimum share that Firm 4 will accept from any coalition. Agreeing to allocate $\$ 2$ to each of the eight customers in $\left(8 \mathrm{~B}, \mathrm{~A}_{4}\right)$ would leave Firm 4 with $\$ 8$ ( $\$ 24$ surplus minus eight customers at $\$ 2$ each). Consequently, Firm 4 can insist on a share of at least $\$ 8$ from any coalition. Were Firm 4 to accept less, it would be giving the eight customers a bounty they could not hope to get from any other firm.

In sum, the coalition ( $4 \mathrm{~B}, \mathrm{~A}_{4}$ ) creates a gain of $\$ 24$, which is large enough to satisfy both the demands of the eight customers for $\$ 2$ each and the demand of one firm for $\$ 8$. Because this coalition is more attractive to every member than any competing coalition, it is within the core. Thus, Telser predicts an efficient equilibrium when demand is 8 .

At demand of 10, in contrast, the core is empty. To satisfy this demand, an efficient social planner would order both Firm 2 and Firm 4 to operate, thus producing ten units at a total cost of $\$ 24$. This coalition $\left(10 \mathrm{~B}, \mathrm{~A}_{2}, \mathrm{~A}_{4}\right)$ produces a surplus of $\$ 26$ (ten customers at $\$ 5$ each, minus Firm 2's $\$ 8$ avoidable costs and Firm 4's $\$ 16$ avoidable cost). But this surplus is too small to keep the group together. Customers will continue to demand at least $\$ 2$ apiece because of the $\left(4 \mathrm{~B}, \mathrm{~A}_{3}\right)$ threat. Firm 4 will continue to demand at least $\$ 8$. These demands alone require a $\$ 28$ surplus (ten customers at $\$ 2$ each, plus $\$ 8$ for Firm 4 ), which exceeds the $\$ 26$ surplus available to the coalition. At this level of demand, no equilibrium 
exists-because of "too much competition."

Telser's second key point is that output quotas can solve the problem of the empty core. To see how, consider the source of instability when demand is 10 . The efficient arrangement $\left(10 \mathrm{~B}, \mathrm{~A}_{2}\right.$, $\mathrm{A}_{4}$ ) would idle Firm 3, but that firm is tempted nonetheless to operate by bidding away customers in blocks of four with offers to each of $\$ 2$. That bid would succeed and would cause $\left(10 \mathrm{~B}, \mathrm{~A}_{2}, \mathrm{~A}_{4}\right)$ to collapse, because its total surplus of $\$ 26$ is too small to satisfy Firm 4's demand for $\$ 8$ and still retain all ten customers by paying their total demand of $\$ 20$. So Firm 3 is the troublemaker in this situation. Telser uses linear programming to devise a system of quotas for every demand level that will restrain troublemakers like Firm 3 from disrupting the efficient equilibrium. At demand of 10 , for instance, Telser calculates the efficient maximum quota for Firm 3 to be two units. At that quota, Firm 3 will be unable to raid the efficient coalition $\left(10 \mathrm{~B}, \mathrm{~A}_{2}, \mathrm{~A}_{4}\right)$. Telser thus argues that voluntary private restraints on output are essential to create a core and thereby to assure the existence of a competitive equilibrium at demand levels like 10.48

Like Bittlingmayer's work, Telser's analysis implies damning criticism of antitrust's per se rule against naked horizontal restraints on price and output. That rule condemns agreements that Telser argues are essential for competitive equilibrium. But, unlike Bittlingmayer, Telser makes no disclaimers about the implications of his work for antitrust policy.

\section{The Core: A Good Idea for Policymakers To Ignore}

Should courts take this literature to heart and change the rule against horizontal restraints? I believe they should not. Translating Telser's use of game theory into judicial doctrine would be remarkably expensive. Moreover, core acolytes have not demonstrated that the expense is warranted; they have yet to show that a problem of even modest dimensions plagues modern industry.

\section{A. Quotas That Work Will Be Pretty Scary}

Telser's quotas aim to improve productive efficiency, but in

4 See Bittlingmayer, 5 Res. L. \& Econ. at 73 (cited in note 1).

40 Telser, 28 J. L. \& Econ. at 291-93 (cited in note 1). Telser's 1978 book makes no mention of private quota arrangements but states that the solution to empty cores "in the real world" can involve the state's "outright ownership of the plants or [its] regulation of the activities of the single firm." Telser, Economic Theory and the Core at 65 (cited in note 11). 
practice they necessarily empower industry to inflict on consumers the cartel costs of overly restricted output, unnecessarily high prices, and, possibly, dampened innovation. To avoid these losses, Telser's proposal would require that judges do what they always have refused to do: use antitrust law to regulate industry as if it were a public utility. There is every reason to respect this traditional judicial reluctance.

1. Core quotas: indistinguishable from evil cartels. Telser proposes an arrangement, which I will call a "core quota," that he describes as a system of property rights essential for stable efficiency and notes that "[s]ince a property right is one that can exclude and restrict, it can be mistaken for a monopolistic restriction." To Telser certainly does not equate "monopolistic restrictions" (or what some have called "plain vanilla cartels") with efficient core quotas. Nevertheless, an effective core quota system must possess powers that would enable it to set industry prices at monopoly levels and, if it were so inclined, to suppress industry innovation. To illustrate this point, I offer a hypothetical about the auto industry-which Telser describes as "the leading example"s1 of a market likely to have an empty core.

Say that auto manufacturers the world over create a World Association for Car Quota Economic Efficiency (WACQEE), a trade association that will specify yearly output quotas for every member auto manufacturer. WACQEE members contract to abide by their yearly allotment from WACQEE or face specified, enormous and legally-enforceable fines. WACQEE orders some plants to close and orders still-operating plants to pay large sums to the closed plants. WACQEE creates a large staff of auditors and production inspectors to ensure each participating manufacturer makes no more than its allotted maximum number of autos. The organization establishes an Innovation Regulation Department to which auto makers agree to submit all innovative ideas about manufacturing and product changes-again on pain of punitive fines. The innovation regulators frequently though not invariably forbid proposed innovations as unacceptable. WACQEE also pools its resources to carry out a concerted campaign to raise the production costs of nonmember auto makers. This campaign establishes agreements with major auto input suppliers and auto retailers to disrupt the supply and distribution chains of nonmembers. WACQEE likewise lobbies a bevy of federal and state bureaus to impose a host of

so Telser, 28 J. L. \& Econ. at 273 (cited in note 1).

s1 Id. at 294. 
crippling regulations and taxes on nonmembers. The campaign ends when the nonmembers agree to enter WACQEE under specified provisions that limit their production-in return for annual cash payments. World auto production falls and car prices rise.

This scenario sounds like an effective cartel operation, and our experience with OPEC has shown the high costs of even a quite imperfect cartel operation. ${ }^{52}$ But this scenario also is perfectly consistent with the operation of a Telserian core quota striving only for productive efficiency. I support this assertion by comparing a simple cartel to a successful core quota system of the sort that Telser describes. As a practical matter, there is no way to distinguish between efficient core quotas and inefficient cartels.

First, core quotas and cartels share the same objective. In pursuit of gains from enforced cooperation, each necessarily aims to prevent individual firms from selling as much as their individual interests direct. Each could achieve this objective by enforcing a set of specified limits on the permissible output level for each firm in the industry.

Second, core quotas and cartels probably would have similar institutional appearances. Telser speaks simply of the need for "some cooperation among the [market] participants," b3 but the needed organization most logically would be intricate and centralized. Effective cartels and core quotas would require similar bureaucracies-"cartel managers" and "core managers," as I will call them respectively-to collect data, to facilitate communication, to calculate optimal production levels, and to assess the effects of changing expected demand and input prices. Additionally, both control systems would seek broad coverage. Effective cartels seek to control all firms in the market, and a core quota arrangement has a similar purpose: to forestall opportunistic and equilibriumdestroying behavior by outsider firms. The relevant market for both cartel and core managers often could be the entire world.

Third, core quotas and cartels need the same powers to be effective. Both need power to set industry-wide output level. ${ }^{54}$ Both

ss See James M. Griffin, OPEC Behavior: A Test of Alternative Hypotheses, 75 Amer. Econ. Rev. 954 (1985) (concluding that OPEC is indeed a cartel).

ss Telser, 28 J. L. \& Econ. at 290 (cited in note 1). See also id. at 293 ("Cooperation among the firms with respect to these [quota] reductions is necessary to attain the efficient result.").

st This need is plain for cartels. Telser's 1978 book makes explicit the core quota's similar need. Telser, Economic Theory and the Core at 65 (cited in note 11) ("decisions governing which plants to operate and at which rates of output must reside in a single control"). This point is implicit in his 1985 article. 
need auditing and penalty powers to combat members' incentives to misrepresent their production levels and costs. ${ }^{.55}$ Both would seek power to govern new entry. ${ }^{58}$ Both would try to penalize outsiders' opportunism by retaliating as ruthlessly as possible. ${ }^{.7}$

Further, both quota systems need power to regulate individual members' decisions to expand capacity. Core and cartel managers alike must cope with changes in expected demand. Accordingly, both sorts of managers would like to manage the details of industry expansions and contractions to ensure industry-wide productive efficiency. ${ }^{58}$ Additionally, both core and cartel managers need power to regulate individual firms' capacity decisions in order to avoid the destabilizing effects of strategic behavior by members. Cartels often divide monopoly profits among members on the basis of their production or capacities. ${ }^{59}$ But members then are tempted to enlarge their capacity to support a claim to an increased quota share. This excess capacity, if actually installed, threatens overproduction and thus endangers the cartel's success. A cartel could forestall this problem by regulating members' capacity investment decisions.

This problem also confronts the efficient core quota. In Telser's numerical illustration, the largest firms operate most often $^{60}$ because they are the most efficient. All firms thus can have an incentive to increase their size over time in order to increase the size of their quota allotments. A socially responsible core quota

${ }^{s}$ Bittlingmayer recounts the nature of the reporting and auditing requirements set by the Addyston cartel. 5 Res. L. \& Econ. at 76-78 (cited in note 1). See also Telser, Economic Theory and the Core at 10 (cited in note 11) (discussing generally the difficulty of preventing cheating). Moreover, firms' complaints to managers could have an identical ring in both the core and in the cartel context: " $\mathrm{A}_{3}$ is selling too much, causing price to fall to a level that spoils the market for the rest of us. You must rationalize production by disciplining that cheater."

se Entry is the nemesis of cartels. Telser acknowledges that a core quota manager likewise must "have the power to prevent the entry of other firms." Economic Theory and the Core at 65 (cited in note 11).

${ }^{87}$ No one is much surprised if cartels make predatory threats to or attacks upon independent price cutters. Judges should expect exactly the same from a core quota system striving for efficiency. Compare Wesley J. Liebeler, Book Review, 66 Calif. L. Rev. 1317, 1328-30 (1978) (reviewing Bork, The Antitrust Paradox), explaining how the coercive boycott in Fashion Guild v. Trade Comm'n, 312 U.S. 457 (1941), might have been an efficient effort by producers to combat opportunistic behavior.

s8 This point remains implicit in Telser's article by virtue of his assumption that expected demand is constant. See Telser, $28 \mathrm{~J}$. L. \& Econ. at 285 (cited in note 1).

59 See Bittlingmayer, 5 Res. L. \& Econ. at 76 (cited in note 1) (reporting pipe cartel's division of a "bonus fund" on the basis of plant capacity).

${ }^{\circ 0}$ See Telser, 28 J. L. \& Econ. at 289, Table 1 (cited in note 1) (largest firm always operates while smallest firm operates only at one of the eight possible demand levels). 
manager must overcome this potential for excessive industry capacity by regulating members' decisions concerning capacity.

Fourth, effective cartels and effective core quotas will have similar market effects: reduced output and increased prices. A cartel hungers for these results when it lacks (as it usually will) the power of perfect price discrimination. Core quotas will have the same effect. Telser's proposal aims to eliminate "excess supply"- the output of opportunistic firms that disrupts the productively efficient supply schedule ${ }^{61}$-because opportunistic firms upset the productively efficient coalition by undercutting its price..$^{62}$ The whole point of a core quota system is to reduce supply and to raise prices.

More speculatively, both cartels and core quotas may try to retard innovation. Cartels shun quality competition, which is a form of competition through innovation. ${ }^{63}$ Core management also may work to suppress other types of innovation. Consider process

61 Id. at 293 ("The imposition of sales quotas . . lowers the excess supply in an optimal fashion.") (emphasis added).

62 Recall the numerical example involving four firms. At a demand of 10 , for instance, productive efficiency calls for firms $\mathrm{A}_{4}$ and $\mathrm{A}_{2}$ to operate. But firm $\mathrm{A}_{3}$ can offer some buyers better terms and "force the price [down] to an upper bound of 3 so that each consumer must gain at least 2." Id. at 289 . This action by $A_{3}$ destroys the stability of the arrangement because even if $A_{2}$ saves no surplus for itself, the productively efficient coalition can tolerate no price lower than $\$ 3.20$. Consequently, Telser's equilibrium-creating output limitation must stop $A_{3}$ from using discounts of less than $\$ 3.20$ to "raid" the globally efficient arrangement. An effective output quota therefore would stop $A_{3}$ 's discounting even though-as Telser stresses, id. at 293 - the quota directly regulates only output and not price.

os Cartels might discourage research and development (or suppress an already-developed innovation) that threatens the status quo because they are aware of their own fragility and ponderousness in the face of market changes. See Telser, 3 J. L. \& Econ. at 96 (cited in note 3) ("cartels are fragile organizations"); id. at 99 ("Though monopolies may respond sluggishly to a changing environment ... the reaction speed of a cartel which turns on the deliberations among the sovereign members must be even slower."). Cartels could seek to discourage research and development by banning it outright or by agreeing to share all developments with cartel members.

But cartelization's effect on innovation can be complex. Cartels that fix minimum prices may spur members to increase their research and development as a means of competing as to quality. See Theodore E. Keeler, Airline Regulation and Market Performance, 3 Bell J. Econ. 399, 421 (1972) (airlines competed away monopoly profits through excess capacity and other forms of "quality" competition). Likewise, cartels that fix capacities may induce members to increase innovation in order to expand capacity through increased productivity. The efficiency of such increased innovation, however, may be highly debatable. In addition, cartelization may make relevant the unsettled Schumpeterian debate over the effect of industry structure on innovation. For a discussion of this point, see Morton I. Kamien and Nancy L. Schwartz, Market Structure and Innovation 84-102 (1982). There is also a growing literature on preemptive innovation. See, e.g., Richard J. Gilbert and David M. G. Newberry, Preemptive Patenting, 72 Amer. Econ. Rev. 514 (1982).

I recognize the uncertainty about whether cartelization will deaden innovation; I suggest only that it might do so. 
innovations. Core quota managers should favor inventions that lower production costs. A firm in a normal market typically overcomes uncertainty about a new idea's effectiveness by trying it on test runs. A core quota manager, however, cannot risk reliance on decentralized innovation testing. Firms seeking to exceed their quotas in bad faith might claim "test production marketing" as a justification. A core quota manager thus might well have to centralize the testing of production innovation ideas: approving the use of genuinely promising ideas and vetoing proposals that seem unpromising.

A core manager might centralize production innovation for a second reason. The interfirm income transfers needed to purchase the cooperation of idled firms in a core quota system could dampen individual firms' incentive to reduce production costs. If a firm succeeds in lowering its costs, the efficient core manager will assign it a larger quota, but also may require it to pay more to the firms whose output is reduced. If so, the successful process innovator will not reap the full benefits of its research and development investment. Accordingly, core managers may have no choice but to centralize process innovations.

Well-counseled cartels could mimic precisely both of these behaviors, to the end of suppressing process innovation.

An efficient core quota manger also should favor product innovations that please consumers. But firms constrained by core quotas will profit if they can evade quota limits by manipulating product categories and altering the characteristics of their over-quota production. ${ }^{64}$ For instance, a car maker has an incentive to transform the rest of its output into some related "innovation," like trucks, vans, golf carts, dune buggies, or jeeps. ${ }^{65}$ To control this

${ }^{64}$ At demand of 10 , for example, Telser's quota permits firm $A_{3}$ to make only two units, where "units" represent some product category like "cars." But $A_{3}$ would find selling four "units" most profitable, although from a social perspective, selling this much would produce an empty core and thus cause disequilibrium. See Telser, 28 J. L. \& Econ. at 289 (cited in note 1).

os For instance, Arnold Harberger, Professor of Economics at UCLA, has pointed out in a lecture that, in an effort to tax only inelastic luxury goods, some Latin American governments have taxed passenger cars more heavily than trucks-a policy that has led to the introduction of kits for converting trucks into passenger vehicles. The Jacob Marschak Interdisciplinary Colloquium on Mathematics in the Behavioral Sciences, UCLA (Apr. 25, 1986) (oral lecture). The 1973 Multi-Fiber Arrangement set quotas on textile imports but ignored an obscure fiber called ramie, which now has flooded the world textile markets. See Lisa Belkin, A Loophole Lets Fiber Surge, N.Y. Times 21, col. 3 (nat'l ed. Sept. 6, 1986). See generally David B. Yoffie, Power and Protectionism 206-30 (1983) (describing several markets in which nations have foiled protectionist treaties by adapting products to exploit treaty loopholes). 
practice, a core quota manager must be prepared to evaluate and license industry innovations on a centralized basis-again, conduct that a cartel could mimic to harmful ends.

Because the two arrangements can share so many features, Telser is correct to suggest that a core quota "can be mistaken for a monopolistic restriction." 68 The powers a core quota manager needs to combat empty cores necessarily enable the manager to cartelize the market as well. I further submit that an industrial entity permitted by law to do all these things will be more tempted to raise price and retard innovation than to fuss about empty cores. To raise price, a cartel need only induce some firm to produce less. To stifle innovation, a cartel need only insist upon the status quo. To calculate and implement Telser's strategy for assuring a core, however, calls for added effort. The industry group must stabilize production for every plant at a precise level, and every change in supply costs or expected demand requires that the arrangement be revised. Innovations must be reviewed in detail to determine their worth. The greater intricacy and coordination these tasks require make their successful achievement less probable. It is no wonder that Bittlingmayer's history of the pipe cartel portrays a group more commonly interested in raising prices than in coordinating efficient production. ${ }^{67}$ Unless judges can save core quota managers from temptation, permitting centralized coordination is apt to yield cartel losses more frequently than efficiency gains.

2. Judicial discipline: neither easy nor likely. Core quota managers will find that their powers for good tempt them to evil. They must be either saintly or regulated. Economists dismiss the former, and regulation is a costly cure-especially when judges undertake it at the detailed level needed to constrain core managers. In practical terms, then, courts face a trilemma of (1) the possibly coreless rivalry of a per se rule; (2) the potentially stable but certainly exploitative cartelization attending abandonment of the per se rule; or (3) a middle point that would amount to public utility regulation, by judges, of many of the world's industries.

Legalizing core quotas would render useless the easy ways of

68 Telser, 28 J. L. \& Econ. at 273 (cited in note 1).

9 Raising price seems to have been a motive for the cartel efforts in $1879,1892,1894$, and 1895 , but coordinated production was a goal only in 1895. See Bittlingmayer, 5 Res. L. \& Econ. at 73 (cited in note 1) (generally inefficient objectives for the 1879 cartel include dividing the work "on a basis equitable to all" and preventing "expansion of present shops or the building of new ones"); id. at 77-80 (cartel first introduced internal auction in 1895, which presumably had some tendency to allocate production efficiently). 
outlawing cartels, because no simple, surefire test distinguishes laudable core management from injurious cartel conduct. In the patent antitrust context, for which a similar problem exists, ${ }^{68}$ Priest proposes that judges essentially look for payments unrelated to the recipient firm's present output level as an earmark that only inefficient arrangements would possess. ${ }^{6 \theta}$ But that test will not distinguish efficient core management. Firms burdened by a quota may refuse to follow it altogether unless their cooperation initially is purchased with redistributive payments that destroy the validity of Priest's "bribe" test in the core quota context." Another possible test, stemming from the fact that Telser's solution forces first one firm and then another to produce zero output, would outlaw quotas that had no such alternating pattern. But this alternating pattern is only an artifact of Telser's particular numerical example, one that cartels could ape in any event.

A remaining ground for a distinction between efficient core management and inefficient cartel conduct focuses on the industry output level that the quota manager selects. Saintly core quotas will produce enough to satisfy all consumers willing to pay more than the product's marginal cost, while a core quota yielding to cartel temptation will restrict output to the monopoly level. ${ }^{71}$ It is a pretty problem to translate this theoretical premise into workable judicial rules. Forcing an entity possessed of monopoly power to mimic the behavior of a competitive market is the familiar problem of utility regulation. The classic policy response has been rateof-return regulation.

Regulatory scholars have had a merry time chronicling the foibles of rate regulation. Breyer summarizes the consensus:

[I]nsofar as cost-of-service ratemaking is advocated as a "cure" for market failure, one must believe that the unregu-

${ }^{88}$ See Ward S. Bowman, Jr., Patent and Antitrust Law 200-26 (1973).

${ }^{68}$ George L. Priest, Cartels and Patent License Arrangements, 20 J. L. \& Econ. 309, 326-30 (1977). But see Louis Kaplow, The Patent-Antitrust Intersection: A Reappraisal, 97 Harv. L. Rev. 1813, 1865-67 (1984) (criticizing Priest's test).

${ }^{30}$ Telser's efficient quota can demand that firms produce nothing. $28 \mathrm{~J}$. L. \& Econ. at 289-91 (cited in note 1). Bittlingmayer reports similarly that the pipe cartel made large internal payments to member firms that "did relatively little work," and he acknowledges the importance of side payments to efficient coordination. 5 Res. L. \& Econ. at 78, 109-10 (cited in note 1 ).

71 Telser described this standard distinction almost two decades ago, remarking that industry "must be prevented from charging a monopoly price, because this would waste social resources. That is, it must be prevented from offering an output where marginal cost equals marginal revenue, because the latter is below the marginal social benefit." Lester $G$. Telser, On the Regulation of Industry: A Note, 77 J. Pol. Econ. 937, 938 (1969). 
lated market is functioning quite badly to warrant the introduction of classical regulation. That is to say, the regulatory process-even when it functions perfectly-cannot reproduce the price signals that a workably competitive marketplace would provide. Thus, only serious market failure will, even arguably, warrant the adoption of cost-of-service ratemaking as a cure. ${ }^{72}$

Without reciting the particulars, it is fair to summarize that any extension of rate regulation on the scale implied by core scholars would be extremely costly. ${ }^{78}$

Courts' questionable institutional competence would escalate the costs of rate regulation on such a scale. The continuous and complex nature of rate regulation would strain the limits of judicial capacity. Rate regulators must monitor ever-changing cost and demand information-a daunting task even for a full-time staff of professionals. Typically, regulatory agencies deal with this problem in ways courts cannot: by doing little else and by ordering regulated firms to submit proposed changes for advance approval. Finally, specialized agencies employ widely gradated sanctions, while courts using antitrust law to supervise core management can force compliance only with the club of treble damages-a fairly blunt instrument with which to try economic brain surgery.

Antitrust courts share this dim view of their capacity to regulate rates, rejecting the very prospect of intricate and ongoing regulatory responsibilities. For example, Judge Wyzanski-even armed with a Harvard economics professor as law clerk, and scarcely famous for his own judicial timidity-rejected ongoing judicial vigilance against United Shoe Company's differential pricing by remarking crisply that the practice's "eradication cannot be accomplished without turning United into a public utility, and the

72 Stephen Breyer, Regulation and Its Reform 59 (1982). Breyer's catalogue of the problems is splendidly clear and concise. See id. at 36-59.

73 In contrast to the narrow confines of traditional rate regulation, Bittlingmayer suggests the empty core is a relatively common problem. See $25 \mathrm{~J}$. L. \& Econ. at 202 (cited in note 1) ("falling long-run average cost, stochastic demand, and some cost associated with having idle plants"-the only necessary conditions-are "quite plausible"). Bittlingmayer specifically mentions the cement, pipe, and iron markets as having had the requisite conditions, 5 Res. L. \& Econ. at 59, 84-85, 87 (cited in note 1), while Telser names airplanes, trains, taxis, publishing, and auto manufacturing, see Economic Theory and the Core at 4445 (cited in note 11); $28 \mathrm{~J}$. L. \& Econ. at 294 (cited in note 1). One suspects that most heavy industry would qualify, and that control must include all relevant foreign firms. This extension of industrial regulation would be spectacular; it would make the regulatory centralization of the New Deal look distinctly small time. 
Court into a public utility commission." "74 Likewise, antitrust law always has avoided the task of restraining monopolists' pricing to a competitive level, largely because of the continuing and discouragingly intricate analysis that such regulatory oversight would require. The very Addyston opinion Bittlingmayer studied warns courts not to "set sail on a sea of doubt,"7s and other courts have repeated that the limits of the judicial role force them to reject a defense that a cartel price is reasonable. ${ }^{76}$

If the world car market and other industries are beset with productive inefficiencies that only can be alleviated by industrywide production coordination, then Telser's quota proposal perhaps is best understood as a call for a form of public utility regulation. ${ }^{77}$ In every other application, such regulation has involved the creation of a permanent and specialized regulatory agency and staff; never has the government relied on judges working through the medium of individual lawsuits to force monopolists to imitate the behavior of a competitive market. But this interpretation of core theory means either that it is of no relevance to antitrust judges or that modifying the per se rule will bring the known costs of unsupervised cartels hand in hand with the uncertain blessings of the core.

\section{B. The Core Is Empty: So What?}

Courts must appreciate the cartel costs of permitting the centralized coordination that Telser's core management sometimes requires for equilibrium. Telser's idea is worth pursuing only if the costs it saves outweigh these losses from cartelization. But when

74 United States v. United Shoe Machinery Corp., 110 F.Supp. 295, 349 (D. Mass. 1953), aff'd per curiam, 347 U.S. 521 (1954).

${ }^{76}$ Addyston Pipe, 85 F. at 283-84.

78 See U.S. v. Socony-Vacuum Oil Co., 310 U.S. 150, 221 (1940); United States v. Trenton Potteries, 273 U.S. 392, 398 (1927).

${ }^{77}$ Implementing socially efficient industrial regulation through judges may be politically impossible as well as hopelessly complex. Regulator "capture" by regulated interests has long plagued the regulation of public utilities and other industries. See Wiley, 99 Harv. L. Rev. at 723-28 (cited in note 4) (surveying literature). The problem also extends to the special interest myopia of legislatures. See Gary S. Becker, A Theory of Competition Among Pressure Groups for Political Influence, 98 Q. J. Econ. 371 (1983). A similar prospect of capture might taint judicial supervision of core management and generally undermine the legitimacy of judicial power.

While most versions of the capture theory are somewhat naive, they nonetheless could have particular bite in circumstances like core management, where the regulation undertaken is complicated and can easily be abused for the benefit of the industries regulated, and where the primary source of the information necessary to set optimal quotas and prices will be the regulated industries themselves. 
we ask just how costly empty cores are likely to be, the rather surprising answer is that, to date, the theory of the core hasn't a clue. Core theory ought to remain unattractive to judges so long as this pig remains in a poke.

Core theory undertakes to identify stable coalitions in a given situation, not to predict which coalition, if any, will ultimately prevail if none or many are stable. A finding that a market situation has no core upsets theorists because they cannot state that the situation has a tendency to align individual conduct with social advantage; the Invisible Hand lurches off on a random walk. In these cases, however, core theory offers absolutely no prediction as to the market result that actually will arise. The theory's prediction is only that games with cores will tend to be in some sense more stable than games without them.

What does this signify in a dynamic world where few expect any market really to achieve and to maintain the blessed condition of equilibrium? Very little, if one interprets Telser's general silence on the subject as agreement with Aivazian and Callen's statement that "[n]o one knows what actually happens when the core is empty. ... This is an empirical question." some demonstration that empty cores are costly, we have no reason to believe they are a problem worth solving. Recall, for example, the "taxi trip" game in which cabs willing to take up to two riders for $\$ 6$ a trip encounter three passengers willing to ride for up to $\$ 7$ each. How will this coreless situation be resolved? Most people with whom I discuss this example predict that the two cabs will somehow manage to carry the three strangers to the airport at mutually acceptable prices. If correct, this casual guess-the only one the literature contains-suggests that the fact of an empty core may entail no efficiency costs.

Bittlingmayer shares Telser's diffidence about the costs of empty cores. He argues that the nature of pipe-making costs fits core theory, but he does nothing to support the idea that empty cores are worth serious worry. In fact, Bittlingmayer dismisses other concerns that might make empty cores seem a fearful prospect. Intuitively, empty cores suggest a sisyphean hell of endless negotiation and recontracting between tentative coalitions-a sort of lawyers' paradise that manufactures only transaction costs. This vision sounds plenty frightening, but Bittlingmayer hastens to reject it: "the theory is not descriptively valid in that sense."

7824 J. L. \& Econ. at 181 (cited in note 22).

75 Res. L. \& Econ. at 121 (cited in note 1). See also Bittlingmayer, 28 J. L. Econ. at 
Neither does he maintain that empty cores necessarily imply instability that is even noticeable, for "unavoidable, even beneficial market frictions" can impart "a measure of stability" when "demand is fairly good." 80

This last qualification seems to be getting us somewhere, suggesting that core theory makes a difference "[d]uring periods of poor demand."81 But Bittlingmayer neither assays the size of this loss nor predicts how often it will appear. Rather than determine the efficiency cost of Addyston's anti-cartel policy, Bittlingmayer argues that three factors indirectly show that empty cores matter: (1) Addyston's pipe makers encountered undesirable cutthroat pipe competition; (2) cutthroat competition condemned the industry therefore either to suboptimal capacity or to cartelization; and (3) the pipe cartel's customers appreciated that the cartel therefore was their best practical option. ${ }^{82}$ These empirical claims all are doubtful.

1. Cutthroat competition? Bittlingmayer notes that during periods of "poor demand," empty cores can cause undesirable cutthroat competition-defined as prices that are too low to cover industry costs. Yet he twice tries and twice fails to show that cutthroat competition existed in Addyston. Bittlingmayer first argues that pipe costs exceeded pipe prices at the end of the 1890s; he does this by subtracting figures on pipe manufacturing costs from data about the market prices of pipe. He concludes that these prices left very little to cover capital, selling, and inventory costs and were therefore unremunerative. ${ }^{83}$

This conclusion is unsatisfactory for two reasons. First, Bittlingmayer compares low prices from some pipe foundries (in the Delaware Valley) in the late 1890 s with high costs from different foundries in 1905-06. ${ }^{84}$ This showing could mean that the Delaware Valley plants were losing money, but it could likewise mean that the Delaware Valley plants were simply more efficient than the others, or that costs generally were lower in the late 1890s than they were in $1905-06 .^{85}$ Neither of the latter two interpretations is

81 (cited in note 1) ("The purpose of this algorithm, it should be stressed, is not to offer a prediction of what will happen in such situations.").

${ }^{80}$ Bittlingmayer, 5 Res. L. \& Econ. at 108 (cited in note 1).

81 Id. at 108-09.

${ }^{82}$ Id. at 107-13.

s3 Id. at 89-93.

84 Id.

ss Bittlingmayer does not make clear whether he discounted his 1906 figures to account for prices that had inflated by about 18 percent since 1896 . See Bureau of the Census, His- 
inconsistent with the Delaware Valley plants turning a full profit at their apparently low prices. Second, even if one does accept his use of 1905-06 cost data from other plants, Bittlingmayer's data generally show remunerative prices during 1896-1900. ${ }^{86}$ Only 1899 shows a loss, but this loss can be explained by factors other than cutthroat competition. Mere coincidence is one possible explanation: assuming perfect competition that results in a long-run industry equilibrium at zero economic profit, the odds that any given industry makes a negative economic profit at any given time should be about 50 percent. In addition, Bittlingmayer admits elsewhere that the price of iron-the major input to pipe making-jumped 60-70 percent in 1899, a "sharp rise . . . generally attributed to the depletion of the Mesabi range in Minnesota."87 That prices lagged one year in response to dramatically increased costs is no proof of a congenitally sick industry.

Bittlingmayer's second effort to demonstrate cutthroat competition focuses on 1896. Comparing two different sources of price information (one from unidentified "southern shops" for February 1896, and the other from two Tennessee pipe makers in March and April 1896) with his cost data from 1906, he finds that average cost exceeded prices in a "relatively good year with firms operating not too far below full capacity." 88

torical Statistics of the United States, Colonial Times to 1970, Part 1 at 212 (1975).

Further, Bittlingmayer's data on the costs of labor, fuel, insurance, taxes, and repairs show that the same costs vary considerably between plants-from $\$ 5.72$ to $\$ 12.48$ per ton. See 5 Res. L. \& Econ. at 65 , Table 1, col. 4. Using costs from other plants at later times to estimate profits for the Delaware River plants thus can be highly unreliable.

${ }^{\text {s6 }}$ Assume an average cost of $\$ 7$ per ton for labor, fuel, insurance, taxes, and repairs ("LFITR")-costs Bittlingmayer says are between $\$ 6$ to $\$ 8$ per ton. See id. at 91 . Subtract this $\$ 7$ per ton cost and Cincinnati iron costs from the Delaware Valley prices to yield the following:

Delaware Valley Pipe Prices Net

Iron Costs and LFITR Cost of $\$ 7$ per ton

$\begin{array}{ll}1896 & \$ 4.31 \\ 1897 & \$ 2.43 \\ 1898 & \$ 2.00 \\ 1899 & \$ 0.58 \\ 1900 & \$ 2.36\end{array}$

Id. at 92 , Table 7 , col. 3 (subtract $\$ 7$ for $1896-1900$ entries). These yearly residuals are generally sufficient to cover the costs of capital, sales, and inventory, which Bittlingmayer elsewhere estimates to be $\$ 2$ to $\$ 3$ per ton. Id. at 101 .

s7 Id. at 88 ; id. at 91 , Fig. 4.

ss Id. at 101-02. 
However, two weaknesses flaw this second showing of cutthroat competition. First, it focuses very narrowly on prices that are likely unrepresentative. The price data cover only a short period (three months or less in 1896) and only some but apparently not all contracts in the region; Bittlingmayer's first study offers the contradictory evidence that industry profits in 1896 were positive and above average. ${ }^{89}$ Second, the below-cost operation by a few firms, even if representative, implies disequilibrium only if the pipe industry did not already possess excessive capacity. If industry capacity were excessive, equilibrium would require a smaller industry. Unremunerative prices then would be the mechanism by which equilibrium would be achieved, not destroyed. Bittlingmayer's claim that little excess capacity existed in 1896 is suspect. He offers no figures on actual capacity utilization in 1896-a point on which data are apparently quite scarce. ${ }^{90}$ Instead, he relies on a January 2, 1896, prediction that 1896 would be a better year than 1895 had been because "Chicago and several other places" had deferred their 1895 pipe demand until 1896. ${ }^{91}$ This prediction looks to have been wrong, according to Bittlingmayer's own data on actual Chicago demand. ${ }^{92}$ Finally, the prediction's figures would yield a minimum capacity utilization rate of only 60 65 percent, not an impressively high minimum rate in any event..$^{93}$

In sum, Bittlingmayer tries to show that, despite its optimal capacity, the pipe industry competed its way to losses during the late 1890s. But his nineteenth century data are too sketchy to prove that cutthroat competition ever harmfully disrupted an opti-

so Id. at 92, Table 7.

00 See Addyston Pipe, 85 F. at 277 ("The evidence as to the capacity of defendants' mills is by no means satisfactory. . . . Nowhere in the large mass of affidavits is there any statement of the per diem capacity of defendants' mills.").

915 Res. L. \& Econ. at 101-02 (cited in note 1).

92 Bittlingmayer's Figure 3, id. at 74, graphs the total miles of water pipe in Chicago from 1870 to 1904 . The slope of the line gives the rate of annual increase, a proxy for annual demand. This slope is constant from 1891 to 1896 , implying flat, not increasing, demand during the relevant period. Further, it is likely that some lag existed between the city's purchase and installation of pipe, and Figure 3's slope decreases from 1896 to 1897, again suggesting that 1896 demand did not increase-and may even have fallen.

${ }^{93}$ The 65 percent figure is Bittlingmayer's. Id. at 102. My own calculation, which assumes that the relevant firms could operate 250 days a year, compares the 375,000 tons of yearly capacity that results from 1,500 tons of daily melting capacity (although recall the lack of good daily capacity data) with demand of 220,000 tons. This gives an estimated 1896 capacity utilization rate of 59 percent. See id. at 71, Table 3 (apparently listing 1,500 tons of daily melting capacity for the Addyston defendants in 1896). Bittlingmayer states that these figures are minima in that they do not reflect anticipated demand from outside "pay" territory, but neither he nor his published sources attempts to estimate this "pay" demand. Id. at 102. 
mally sized industry. Moreover, even if his effort had succeeded, Bittlingmayer still would not have addressed the key empirical questions that should concern judges: whether cutthroat competition is a common consequence of empty cores, and whether the phenomenon, when it does occur, produces significant inefficiency.

2. Suboptimal capacity versus cartelization? Bittlingmayer contends that conditions like those in Addyston force the market to face suboptimal capacity if antitrust bars merger and cartelization. ${ }^{94}$ But Bittlingmayer again offers no hint about how costly and hence how important this suboptimality will be. More fundamentally, there is reason to doubt his prediction that suboptimal capacity is a necessary consequence of the per se rule's condemnation of cartel cooperation; an empty core does not necessarily imply suboptimal capacity. ${ }^{95}$

For example, cycles in firm operation can approximate optimal capacity over time. Figure 1 depicts the marginal costs of two identical firms facing a demand curve that does not allow short-run equilibrium.

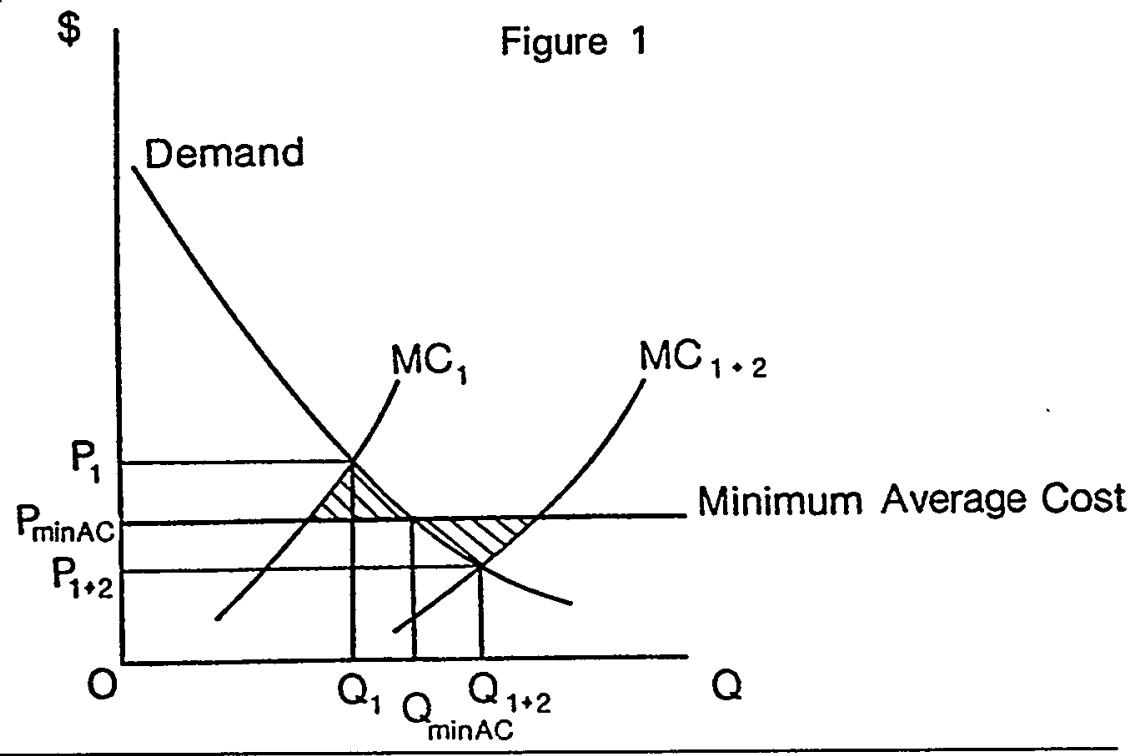

or Id. at 109. Telser also hints that, absent cooperation, empty cores mean small plants or short-term arrangements that are inefficient. See $28 \mathrm{~J}$. L. \& Econ. at 276-77 (cited in note 1).

95 My examples assume a conventional, known demand curve. When demand is uncertain, Telser argues that capacity will be suboptimal if customers have unpredictable demands to which they attach a value greater than a firm's marginal supply cost. $28 \mathrm{~J}$. L. \& Econ. at 277-85 (cited in note 1). These customers presumably will seek contingent arrangements with suppliers-devices such as options or long-term contracts that increase certainty and that ordinarily require no cartel-like cooperation among firms. In addition, reasoning about a known demand curve is tractable, while analytical complexities have prevented a general statement of the optimal capacity distribution when demand is uncertain. See Bittlingmayer, 25 J. L. \& Econ. at 207 \& $n .9$ (cited in note 1). Finally, treating demand as certain approximates cases where the duration of demand levels is long compared to the time required for a plant to change output level. 
This market has no core and no short-run equilibrium point because demand and cost conditions leave room for fewer than two full-sized producers. If one firm operates alone, it will produce output $Q_{1}$ at the high price $P_{1}$; operating two firms produces output $\mathrm{Q}_{1+2}$ at the unsustainable, money-losing price $\mathrm{P}_{1+2 .{ }^{96}}$ Jacob Viner suggested that in these circumstances output will oscillate between $Q_{1}$ and $Q_{1}+2 .{ }^{97}$ It is plausible that the fluctuations in price and output over several periods could average out to the efficient levels of $P_{\min A C}$ and $Q_{\operatorname{minAC}}$. Telser criticizes Viner for calling such cyclical fluctuation "a stable equilibrium." Whether or not it is semantically accurate to term a cycle "stable," empty cores do not necessarily cause any efficiency loss from suboptimal capacity,

Firms in a coreless market also might react to instability by changing plant size. Suppose, in our illustration, that Firm 2 tires of cycling in and out of operation because of a new conviction that Firm 1 will never change its behavior. Figure 2 illustrates how Firm 2 might then reduce its capacity so that, given its rival's size,

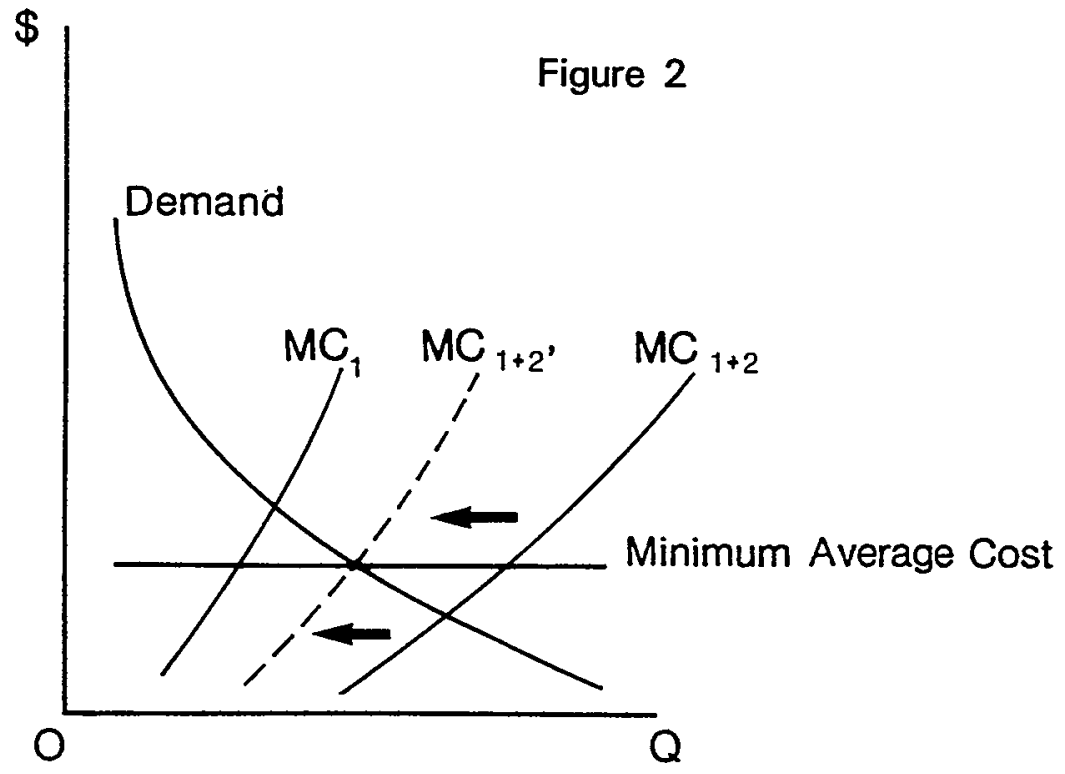

98 Because the cross-hatched triangles are of equal size, optimal production is indifferent as to whether one plant or two operates. The model for this graph and its accompanying explanation are in Telser, Economic Theory and the Core at 114, Fig. 3.3 (cited in note 11). Bittlingmayer uses the same graph. See 25 J. L. \& Econ. at 205 (cited in note 1).

$\Re 7$ Jacob Viner, Cost Curves and Supply Curves, reprinted in American Economic Association, Readings in Price Theory 198, 212 (1952). Imagine, for instance, that Firm 1 operates alone in period 1. Entry costs are low. High prices induce the entry, in period 2, of Firm 2 , which expects some lag and hence profit opportunity before prices fall to $P_{1+2}$. In period 3 , low prices force one firm to exit, and the cycle continues.

${ }^{98}$ Telser, Economic Theory and the Core at 387 n.4 (cited in note 11). 
$\mathrm{MC}_{1+2}$ intersects the demand curve at a sustainable price equal to marginal cost.

This capital adjustment would solve the problem of an empty core by creating an efficient competitive equilibrium free of suboptimal capacity.

I offer these examples as counterpoints to Bittlingmayer's assertion that a per se rule against cartels is "bound to" incur significant social costs because of the possibility of an empty core. ${ }^{99} \mathrm{I}$ do not claim that capacity adjustments will always mitigate Vinerian "cycling"; my point is that no core acolyte has shown that it will not. Neither do I claim that capacity adjustments or cycling in and out of operation are costless; my point is just that no core disciple has shown that it is damningly expensive. Finally, I do not even claim the conduct in these examples necessarily will occur; my point is just that game theory has been notoriously unsuccessful in reaching robust conclusions about the outcome of oligopolistic situations and, in particular, has not shown that coreless markets produce insufficient capacity. ${ }^{100}$ No one knows what will result from an empty core. Consequently, judges now have no basis for accepting assertions that an empty core necessarily implies significant-or even any-economic loss. And neither do other relevant policymakers. Legislators drive with their eyes closed if they weaken anti-cartel policy knowing that the cost of allowing cartels is likely to be significant but that the cost of banning them may not even exist. Nor should antitrust enforcement officials allocate their resources on the basis of such an inconclusive theory.

3. Happy cartel customers? To support his thesis that empty cores dictate seller cooperation, Bittlingmayer suggests that pipe buyers understood this point and supported the Addyston cartel. $^{101}$ This is a surpassingly odd argument to make about a cartel that strove-successfully for a time-to conceal itself from its customers. ${ }^{102}$ Bittlingmayer rests his claim on two facts. First, the cities of Atlanta and St. Louis, which had patronized the cartel, decided not to sue it once they learned of its existence. But

"Bittlingmayer, 5 Res. L. \& Econ. at 114 (cited in note 1). Bittlingmayer does concede, however, that the per se rule and the rule of reason "may indeed be the best that courts with imperfect knowledge can enforce." Id.

100 For instance, ocean shipping is an industry with cost technology that seems to fit Telser's theory neatly. Yet the persistent (and unproven) industry complaint has been of over capacity. See, e.g., Hard Times on the High Seas, The Economist 100 (June 15, 1985).

102 See 5 Res. L. \& Econ. at 105-07, 113 (cited in note 1). existed).

102 See Addyston Pipe, 85 F. at 276 (cartel members "vigorously denied" a combination 
Bittlingmayer himself refutes this first point. He recounts that the cities abstained from suit, not out of appreciation for the actions of a successful and beneficial cartel, but because both judged their legal cases to be weak ${ }^{\mathbf{1 0 3}}$ and because St. Louis did not "feel that the city has been or can be defrauded by any combinations."104

Bittlingmayer's second proof consists of fifty-seven affidavits from municipal pipe buyers averring that cartel prices were reasonable. However, the cartel's lawyers apparently manufactured these affadavits solely for purposes of litigation. ${ }^{105}$ Bittlingmayer's credulous acceptance of the claim that buyers hankered for a cartel would have delighted the lawyer who conceived of the affidavit tactic, but this argument ought not to command respect today.

4. Summary. Telser and Bittlingmayer use core theory to describe a competitive evil with ghost-like qualities: uncertain manifestations, costly riddance, and a tendency to divert to mischief those who would combat it. Policymakers, even those concerned solely with economic efficiency, ought not let this spirit move them. Before changing the status quo to remedy them, a judge must believe empty cores cause losses that outweigh the costs of their cure. But as yet the proponents of core theory have provided

${ }^{103}$ As indeed they probably were at the time, under $E$. C. Knight's restricted view of interstate commerce. See United States v. E. C. Knight Co., 156 U.S. 1 (1895) (merger of sugar refineries to create virtual monopoly of U.S. market held to be beyond the Sherman Act because manufacture for export to other states is insufficient for federal commerce clause jurisdiction). See also Bittlingmayer, 5 Res. L. \& Econ. at 82 (cited in note 1) (E.C. Knight figured in Atlanta's decision not to prosecute the Addyston cartel).

${ }^{104} 5$ Res. L. \& Econ. at 82-83 (cited in note 1) (quoting St. Louis City Counselor, who nonetheless refused to submit an affidavit on behalf of the Addyston defendants).

${ }^{105}$ Addyston Pipe, 85 F. at 293 (all were "drawn by the same hand or from the same model"). Defense attorneys apparently thought highly of affidavits as strategy; they also submitted affidavits claiming that cartel managers "did not know what interstate commerce was, and, therefore, that they could not have combined to restrain it." Id. at 301 . This creative defense also failed.

The buyer affidavits are otherwise suspect. Affiants signed the statements. But these purchasing officials were apparently not cross-examined, so nothing is known of their motives or possible relationships with the cartel. Three factors suggest their unreliable character. First, the affidavits all came from municipal rather than private buyers, and Bittlingmayer suggests that the "alert" buyers were "generally the private buyers." See 5 Res. L. \& Econ. at 89 (cited in note 1). See generally Lincoln Steffens, The Shame of the Cities (1904) (describing rampant bribery and corruption in nineteenth-century cities, specifically including St. Louis). Second, the affiant from Atlanta blandly declared that dealings with one cartel member (the Anniston firm) had been "uniformly fair" even though the record revealed that the firm twice had subverted Atlanta's competitive bidding process. See Bittlingmayer, 5 Res. L. \& Econ. at 106; Addyston Pipe, 85 F. at 276. Third, Atlanta's declaration of fairness also is contradicted by a more knowledgeable source: a fellow cartel company that complained to the Anniston firm that its prices to Atlanta were "entirely out of all reason," thus causing "a bad feeling and an agitation against the combination." 85 F. at 27677. 
no basis for that belief. ${ }^{108}$

\section{The Irrelevance of Cartel Efficiency}

So far I have taken only a narrow view of the question that core theory poses for antitrust law: will the efficiency gains from abandoning the per se rule in response to core theory outweigh the accompanying efficiency losses? Economists are familiar with evaluating efficiency tradeoffs of this sort and will find the focus on efficiency quite natural. ${ }^{107}$ It should not seem so to judges, who ought to be even less impressed by core management's virtues and more worried about cartel costs when they replace the goal of efficiency with the distributive goal of antitrust law.

Economists have made a good toy of the Sherman Act by assuming that its only relevant goal is to achieve economic efficiency. If they bother at all to defend this assumption, they usually do so simply by citing Judge Bork's influential scholarship on the matter. ${ }^{108}$ But Bork's view that Congress focused exclusively on efficiency is problematic. For example, Robert Lande argues that Congress favored a distributive goal that entitles ultimate or household consumers to the wealth they would receive from transacting with rivalrous producers. ${ }^{109}$ In Lande's view, the role of antitrust law is to guard consumers against producer restraints that would appropriate this wealth. There are many reasons to believe that judges more closely follow congressional intent when they define antitrust's goal as distributive justice rather than as economic

${ }^{108}$ Moreover, core theorists have not shown the validity of their theory's assumption of fixed plant capacity. Many margins usually exist along which markets can vary output rates for plants with apparently fixed capacities. For instance, Telser illustrates his crucial notion of an avoidable cost in a fixed capacity setting by referring to the airline industry. Telser, Economic Theory and the Core at $\mathbf{4 4 - 4 5}$ (cited in note 11). Airplanes do seem to be able to carry passengers only in fixed capacities: planeloads. But in fact airlines can choose from a variety of plane sizes. Using a "hub" system and a variety of alternative route combinations, airlines can operate at a variety of capacities-even using a single plane size. Further, if planes are small relative to the size of the market (daily or hourly demand), airlines no longer face the fixed firm capacity constraint that is the very premise for the problem that core theory defines.

${ }_{107}$ See, e.g., Harold Demsetz, Information and Efficiency: Another Viewpoint, $12 \mathrm{~J} . \mathrm{L}$. \& Econ. 1 (1969); Oliver E. Williamson, Economies as an Antitrust Defense: The Welfare Tradeoffs, 58 Amer. Econ. Rev. 18, 21-23 (1968).

108 See Robert H. Bork, Legislative Intent and the Policy of the Sherman Act, 9 J. L. \& Econ. 7 (1966); Bork, The Antitrust Paradox ch. 2 at 50-66 (cited in note 25).

${ }^{102}$ Robert H. Lande, Wealth Transfers as the Original and Primary Concern of Antitrust: The Efficiency Interpretation Challenged, 34 Hastings L. J. 65 (1982). See also Louis Kaplow, The Accuracy of Traditional Market Power Analysis and A Direct Adjustment Alternative, 95 Harv. L. Rev. 1817, 1825 (1982); Wiley, 99 Harv. L. Rev. at 748-51 (cited in note 4). 
efficiency. ${ }^{110}$

This debate over goals typically does not matter. Consumers benefit when an efficient market offers goods to them at low longrun prices, in which case the goals of efficiency and distributive justice converge. But Lande's point is significant when the two goals conflict. Core quotas could provide one such instance.

Core quotas aim to improve productive efficiency but simultaneously permit monopoly pricing. In the context of core quotas, the distributive goal of antitrust renders gains in productive efficiency legally irrelevant unless they are remarkably large. The productive gain from core quota coordination not only must outweigh the allocative efficiency loss; it also must swamp the effect of monopoly pricing to the point of reducing absolutely the long run prices to consumers.

Recall that in Telser's numerical example, at demand of 10, Firms 2 and 4 operate the optimal supply combination because they can make ten units at the low cost of $\$ 24$ ( $\$ 8$ cost for Firm 2 plus $\$ 16$ cost for Firm 4). But recall also that the core is empty at this demand level; we know this combination is unstable but have no idea what instability will beget. Assume for the sake of argument, however, that an empty core causes a substantial loss in productive efficiency that outweighs the corresponding cartel loss from allowing core quotas. In particular, assume that without quota restraints Firms 3 and 4 (rather than 2 and 4) operate; that the cartel suppresses no innovations; and that all ten consumers are willing to pay $\$ 5$ each. These assumptions mean that the quota can save $\$ 4$ in production cost (by scheduling Firm 2 rather than Firm 3 ) and that allocative loss is zero (because the quota's monopoly price of $\$ 5$ discourages no buyers). Imposing the core quota makes sense from the efficiency perspective.

However, distributive justice for consumers demands the opposite conclusion. If unrestrained rivalry before the quota drove prices down to cost, market trades then yielded customers a surplus of $\$ 22$ (ten customers willing to pay $\$ 5$ each, minus $\$ 28$ production costs). Imposing a quota means consumers now get nothing. They pay $\$ 5$ for goods they value at exactly $\$ 5$. The producers' quota thus has robbed consumers of what is, in Lande's view, their $\$ 22$ total distributive entitlement. The distributive goal counts the quota's $\$ 4$ productive gain as no justification whatsoever: consum-

110 See John Shepard Wiley Jr., The Berkeley Rent Control Case: Treating Victims as Villains, 1986 S.Ct. Rev. 157, 163-66; John Shepard Wiley Jr., "After Chicago": An Exaggerated Demise?, 1986 Duke L. J. 1003, 1011-13. 
ers never see it, and this analysis counts consumer justice as the objective of the Sherman Act. ${ }^{11}$ Telser's solution thus focuses on a benefit irrelevant to antitrust judges and ignores the distributive cost that looms as those judges' central concern. Proper account of antitrust goals thus further moots the theory of the core.

\section{Conclusion}

Proponents of core theory understand their challenge to conventional antitrust wisdom to be profound. I do not concentrate on the theoretical validity of this challenge. Instead I suggest that currently it is irrelevant to its logical policy audience: antitrust judges. Telser's proposed quotas would require judges to modify significantly antitrust's key per se prohibition on cartel activity. The proposal is a poor idea. The chore of distinguishing between efficient and inefficient quotas would place federal courts in the office of public utility regulators-a hopelessly unwieldy role for judges. Given the impracticality of judicial utility regulation, Telser's proposal would trade the chance of reducing production costs for the certainty of cartelization. There is good reason to think that the trade is a bad deal. Core theory has yet to offer reasons to the contrary. Moreover, the most credible goal for antitrust-blocking producers from appropriating consumers' entitlements to wealth-renders the entire enterprise misguided unless productive gains from core quotas are staggering. No one even sug-' gests that this is true.

In the last analysis, many things remain unclear about core theory. One thing does not. If the question is whether core theory presently should lead judges to weaken antitrust's hostility to cartels, the answer must be no.

11' Society could change every efficiency gain to consumers' advantage if it could, without administrative cost, limit production to the efficient supply combination and transfer wealth back to consumers via taxation. But like price regulation, redistributive taxation is beyond the scope of the judges who administer the Sherman Act. 